\title{
Locally produced relaxin may affect testis and vas deferens function in rats
}

\author{
Lais Cavalca Cardoso, Aline Rosa Nascimento, Carine Royer, Catarina Segreti Porto \\ and Maria Fatima Magalhaes Lazari \\ Section of Experimental Endocrinology, Department of Pharmacology, Universidade Federal de São Paulo, Escola \\ Paulista de Medicina, Rua Três de maio 100, INFAR, Vila Clementino, SP 04044-020 São Paulo, Brazil
}

Correspondence should be addressed to M F M Lazari; Email: lazari@unifesp.br

\begin{abstract}
We have previously shown that the rat testis and vas deferens contain high levels of the relaxin receptor, RXFP1. The present study was undertaken to determine the expression of relaxin in these tissues, and the effect of exogenous relaxin on Sertoli cell proliferation and on the mRNA levels of some proteins that may contribute to epithelial secretion and tissue reorganization in the vas deferens. Relaxin mRNA levels in testis and vas deferens were much lower than in the prostate. Sertoli cells seem to be an important source of relaxin mRNA in testis. Relaxin immunoreactivity was detected in the seminiferous epithelium but not in the interstitial compartment. The relaxin precursor was expressed in the vas deferens, and relaxin immunoreactivity was detected in apical cells of the vas deferens. Castration, but not treatment with the anti-estrogen $\mathrm{ICI} 182,780$, dramatically reduced relaxin mRNA levels in the prostate and vas deferens, and this effect was prevented by testosterone. Rxfp1 mRNA levels in the vas deferens and prostate were not affected by castration or treatment with ICI 182,780. Exogenous relaxin increased the incorporation of ${ }^{3} \mathrm{H}$-thymidine in cultured Sertoli cells, and treatment of the vas deferens with $100 \mathrm{ng} / \mathrm{ml}$ relaxin increased the mRNA levels for the cystic fibrosis chloride channel (cystic fibrosis transmembrane regulator) about three times, and doubled mRNA levels for the inducible form of nitric oxide synthase and metalloproteinase 7. These results suggest that locally produced relaxin acts as an autocrine or paracrine agent in the testis and vas deferens to affect spermatogenesis and seminal fluid composition.

Reproduction (2010) 139 185-196
\end{abstract}

\section{Introduction}

Relaxin is a $6 \mathrm{kDa}$ peptide with a structure similar to insulin. Relaxin has a wide spectrum of actions (Sherwood 2004, Dschietzig et al. 2006). Its role in female reproduction is well known: relaxin is important during pregnancy and in preparation for parturition (Sherwood 2004), and it stimulates growth of the uterus in prepubertal animals (Bagnell et al. 1993, Yan et al. $2006,2008)$. The main source of relaxin in females is the corpus luteum, but relaxin mRNA and/or protein have been detected also in preovulatory follicles (Bagnell et al. 1993, Einspanier et al. 1997, Ohleth et al. 1998), and it has been suggested that relaxin exerts a paracrine or autocrine role in the ovary, promoting follicular growth and ovulation.

Increasing evidence shows that relaxin is important also for male reproduction. In most species, the prostate is the main source of the hormone (reviewed in Sherwood (1994, 2004)). In humans, the relaxin gene and protein are expressed in the prostate (Sokol et al. 1989, Gunnersen et al. 1996, Garibay-Tupas et al. 2000), but relaxin immunoreactivity is also present in the seminal vesicles and the ampular region of the vas deferens (Yki-Järvinen et al. 1983). In the boar, the seminal vesicle seems to be the main source of the hormone (Kohsaka et al. 1992), although a relaxin-like antigen may also be present in the testis (Dubois \& Dacheux 1978). In the shark, the testis is a major source of relaxin (Steinetz et al. 1998). In mice, relaxin mRNA is present in the testis and prostate (Samuel et al. 2003a, $2003 \mathrm{~b}$ ). The sources of relaxin in the male rat are controversial. Immunohistochemical studies failed to demonstrate relaxin protein in the testis, prostate, seminal vesicle, and epididymis (Anderson et al. 1986), but relaxin mRNA was detected in the prostate and testis (Gunnersen et al. 1995).

Initially, it was thought that the relaxin produced in the male reproductive tract would be released exclusively in the seminal fluid to influence sperm motility (Sasaki et al. 2001, Kohsaka et al. 2003, Sherwood 2004). However, studies with relaxin gene knockout animals (M1RKO) show that relaxin also plays a role in growth and development of the male reproductive system (Samuel et al. 2003a). Male M1RKO show retarded growth of the testis, epididymis, prostate and seminal vesicle, 
decreased sperm maturation, epithelial proliferation in the prostate, and increased apoptosis in testis and prostate (Samuel et al. 2003a). Deposition of collagen is increased in tissues of the male reproductive tract of M1RKO (Samuel et al. 2003a, 2005).

While relaxin gene knockout animals have provided a valuable demonstration that relaxin is important for the growth and development of the male reproductive tract, the role of relaxin in the adult remains unclear. We have previously shown that mRNA for the relaxin receptor RXFP1 is widely distributed in the reproductive tract of the male rat (Filonzi et al. 2007). Testis and vas deferens were the tissues with the highest levels of Rxfp1 mRNA. In the testis, RXFP1 immunoreactivity was present in Sertoli cells and elongated spermatids; in the vas deferens, RXFP1 was detected in the smooth muscle layer and in the apical part of epithelial cells. However, relaxin produced in the prostate would have no access to relaxin receptors in the testis and vas deferens, and therefore the role of these receptors remains an enigma. Although relaxin receptors are present in the muscular layer of the vas deferens, they do not appear to affect contractile activity (Filonzi et al. 2007).

The present study was done on two tissues of the reproductive tract of the male rat that express high level of RXFP1 receptors: testis and vas deferens. Our study explored: 1) the expression of relaxin mRNA and protein in these tissues; 2) the role of relaxin on Sertoli cell proliferation and on expression of genes that may affect ion transport and tissue reorganization in the vas deferens; 3) the regulation of relaxin expression by maturation and sex steroids. Our results suggest that relaxin in the testis and vas deferens has an autocrine or paracrine role.

\section{Results}

\section{Relaxin gene expression in the testis, vas deferens, and prostate}

The levels of relaxin transcript in testis and vas deferens from adult animals were similar and markedly lower than in the prostate (quantitative RT-PCR (qRT-PCR), Fig. 1, Newman-Keuls test, $P<0.05)$. Levels of relaxin transcripts were at least as high in primary cultures of Sertoli cells as in the whole testis, suggesting that Sertoli cells are an important source of relaxin.

We evaluated a relaxin antibody (N18, Santa Cruz Biotechnology, San Diego, CA, USA) by immunohistochemistry on two tissues known to produce large amounts of relaxin: prostate from adult rats and ovary from rats on the 21 st day of pregnancy (Fig. 2A and B). We observed the expected labeling in the corpus luteum (Fig. 2A) and in the glandular epithelium of prostate (Fig. 2B), in accordance with previously described data (Golos et al. 1984, Sokol et al. 1989).

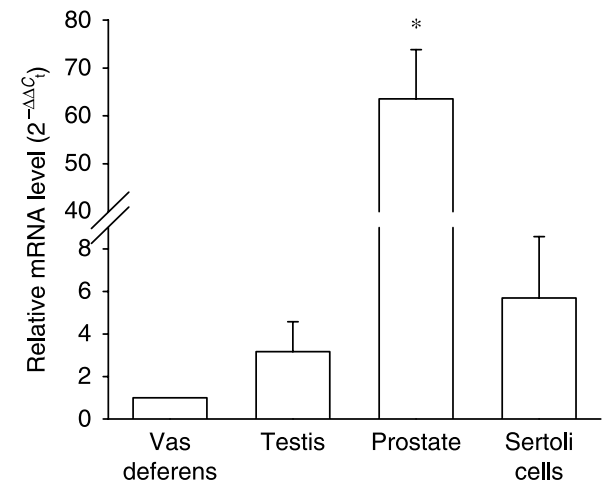

Figure 1 Real-time PCR analysis of the amount of relaxin transcript in testis, vas deferens, prostate, and primary culture of Sertoli cells. Values were normalized using $\beta$-actin as endogenous control, and are expressed as relative values using the vas deferens as a calibrator of each experiment (means \pm S.E.M. of three independent experiments performed in triplicate). ${ }^{*}$ Indicates a statistically significant difference from the other values ( $P<0.05$, ANOVA followed by Newman-Keuls).

Western blots with the N18 antibody showed a band with an apparent molecular mass of preprorelaxin $(21 \mathrm{kDa})$ in the vas deferens, testis, and in tissues used as positive controls: ovary from pregnant rats and prostate (Fig. 2C and D). The ovary also contained a protein with apparent molecular mass of $42 \mathrm{kDa}$, which may be a preprorelaxin dimer that was first detected in arteries (Novak et al. 2006). In the vas deferens, a protein of about $16 \mathrm{kDa}$ apparent molecular mass, probably related to a prorelaxin, was detected that predominated over the $21 \mathrm{kDa}$ molecular form. The mature $6 \mathrm{kDa}$ peptide was detected only in the prostate (Fig. 2C). Preincubation of the primary antibody with lysate of the ovary from a pregnant rat, a source rich in relaxin, completely eliminated the bands of 42,21 , and $16 \mathrm{kDa}$, and considerably reduced the $6 \mathrm{kDa}$ form (Fig. 2D).

\section{Localization of relaxin in the testis and effect of relaxin on Sertoli cell proliferation}

To identify the cells that account for relaxin expression in the testes, immunohistochemistry with an anti-rat relaxin 1 antibody (Abcam, Cambridge, MA, USA) was performed. This antibody recognizes the relaxin precursor but not the mature peptide, and therefore indicates regions of hormone synthesis rather than regions of only storage of the fully processed hormone. In testis from immature 15-day-old animals, relaxin immunoreactivity was mainly detected in Sertoli cells, and no specific immunoreactivity was detected in the Leydig cells or other cells of the interstitium (Fig. 3A and B). In testis from adult 120-day-old rats, relaxin immunoreactivity was present in Sertoli cells and restricted to the seminiferous epithelium (Fig. 3C and D). Pachytene spermatocytes showed strong immunoreactivity, but immunolabeling was also detected in spermatids (Fig. 3C). 


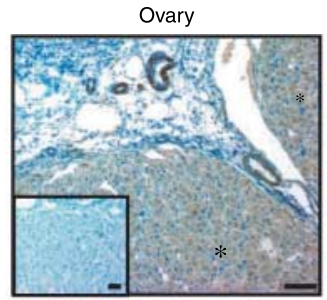

C

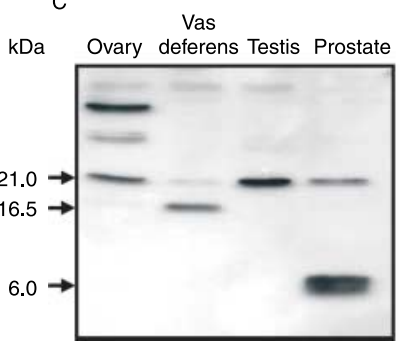

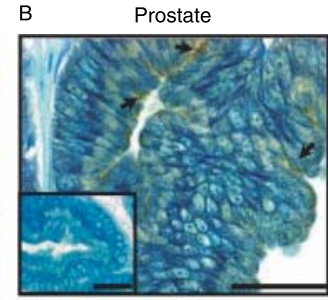

D

Vas
Ovary deferens Testis Prostate kDa

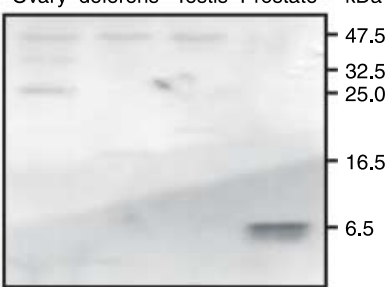

Figure 2 ( $A$ and $B$ ) Immunohistochemical determination of relaxin expression in the ovary of pregnant rat $(\mathrm{A})$ and in the prostate $(\mathrm{B})$ with N18 anti-relaxin antibody (1:100 dilution). Specific labeling (asterisk) was observed in luteal cells of the corpus luteum and in the apical portion of cells of the glandular epithelium of the prostate (arrows). Insets show negative controls incubated in the absence of primary antibody. Scale bars are $10 \mu \mathrm{m}$. (C and D) Western blot analysis of relaxin expression in testis, vas deferens, and prostate with N20 antibody. Panel D shows nonspecific immunoreactions seen after preincubation of the primary antibody with a relaxin source (ovary of 21-day pregnant rat). Representative example from three to five independent experiments. Arrows indicate bands that correspond to the relaxin precursors or mature relaxin.

Since relaxin is known to stimulate cell proliferation in the female reproductive tract (Bagnell et al. 1993, Zhang \& Bagnell 1993, Ohleth \& Bagnell 1995, Lee et al. 2005, Masters et al. 2007), we tested the effect of relaxin on proliferation of Sertoli cells. Treatment with 100 and $200 \mathrm{ng} / \mathrm{ml}$ relaxin increased the incorporation of ${ }^{3} \mathrm{H}$-thymidine by $33 \pm 6$ and $59 \pm 8 \%$ respectively (Fig. 4). $\mathrm{FSH}$, a classically known stimulator of Sertoli cell proliferation, increased ${ }^{3} \mathrm{H}$-thymidine incorporation as expected (by $40 \pm 15 \%$ with $50 \mathrm{ng} / \mathrm{ml} \mathrm{FSH}$ ). The effects of relaxin and FSH were not additive or synergistic (Fig. 4).

\section{Expression of relaxin, metalloproteinase 7, and cystic fibrosis transmembrane regulator in the epithelial layer of the vas deferens and effects of relaxin on gene transcription in the rat vas deferens}

The presence of relaxin receptors in the epithelial layer of the vas deferens (Filonzi et al. 2007) led us to investigate whether relaxin affects the mRNA levels of proteins that may contribute to epithelial secretion and tissue reorganization in the vas deferens. Immunohistochemistry with the anti-rat relaxin 1 (Abcam) showed immunoreactivity in the apical cells of the epithelium of the proximal region of the vas deferens (Fig. 5A).
Interestingly, most of the labeled apical cells had labeling near the basement membrane. No relaxin immunoreactivity was detected in the distal region of the vas deferens, where the apical cells are not present.

Potential targets for regulation by relaxin include metalloproteinase 7 (MMP7, see Filonzi et al. 2007) and the cystic fibrosis transmembrane regulator (CFTR), a multifunctional protein that is known to be a cAMPactivated $\mathrm{Cl}^{-}$channel, and which is important for fluid transport in the excurrent ducts of the male tract (Leung et al. 2001, Ruz et al. 2004, Pietrement et al. 2008). MMP7 immunoreactivity was restricted to the supranuclear region of epithelial cells of the vas deferens (Fig. 5B). CFTR immunoreactivity was detected in the epithelial layer of the vas deferens, particularly in the apical region of the epithelial cells and in some microvilli (Fig. 5C).

We next investigated whether relaxin affects the transcription of Cftr and Mmp7, and two additional genes known to be affected by relaxin in other tissues, Mmp2 and Mmp9 (Lenhart et al. 2001, Mookerjee et al. 2005, Jeyabalan et al. 2006, 2007). As shown in Fig. 6A, relaxin increased the $\mathrm{Cftr}$ transcripts in the vas deferens threefold $(P<0.05 ; N=4)$. We have previously detected by northern blot that mRNA levels for Mmp7 were increased by incubation of the vas deferens with $1 \mu \mathrm{g} / \mathrm{ml}$ relaxin (Filonzi et al. 2007). Here, we tested whether lower concentrations of relaxin are effective. There was
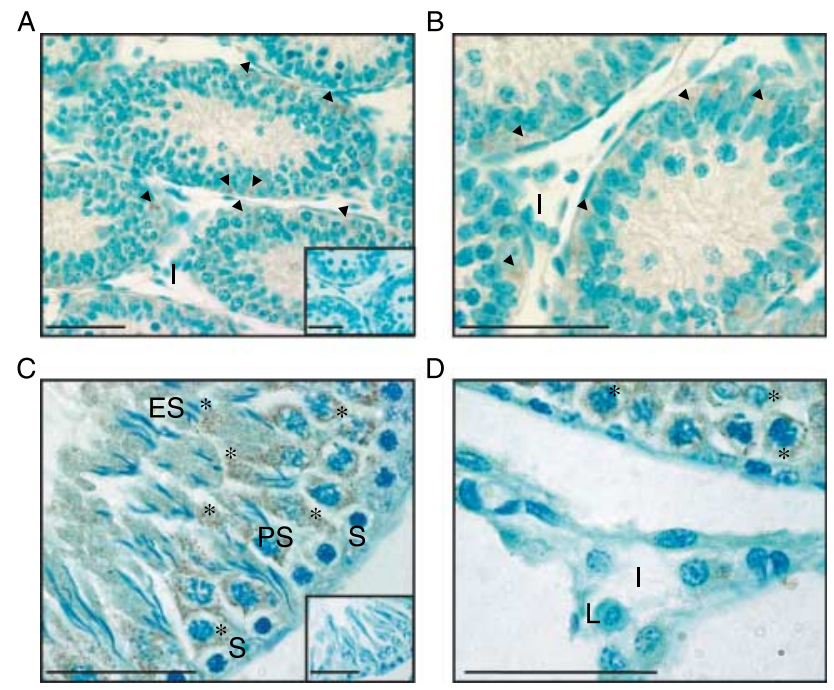

Figure 3 Immunohistochemical analysis of expression of relaxin in testes with the anti-rat relaxin 1 antibody (ab70803, Abcam). (A and B) Testes from immature, 15-day-old rats. Specific immunoreaction was observed in Sertoli cells (arrow heads); (C and D) Testes from adult, 120-day-old rats. Specific immunoreaction (asterisks) was observed in the seminiferous epithelium but not in the interstitial compartment (I). Representative example of three different analyses. Insets show negative controls incubated in the absence of the primary antibody. Scale bars are $10 \mu \mathrm{m}$. ES, elongated spermatids; I, interstitium; L, Leydig cells; PS, pachytene spermatocytes; S, Sertoli cells. 


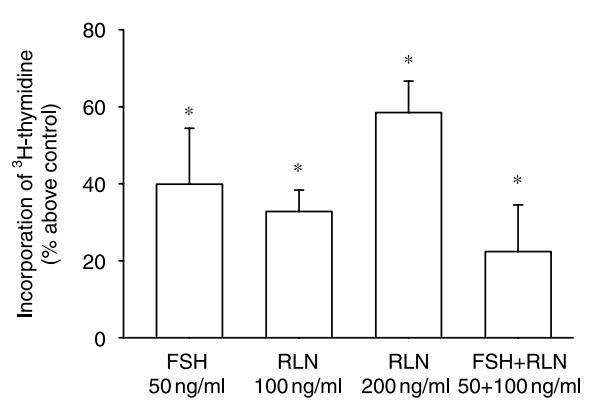

Figure 4 Effect of relaxin on proliferation of Sertoli cells measured by incorporation of [methyl $-{ }^{3} \mathrm{H}$ ] thymidine. Cells were incubated in the absence (control) or presence of $\mathrm{FSH}(50 \mathrm{ng} / \mathrm{ml})$, relaxin (RLN, 100 and $200 \mathrm{ng} / \mathrm{ml}$ ), or FSH+RLN (50 and $100 \mathrm{ng} / \mathrm{ml}$ respectively) for $24 \mathrm{~h}$. Results were expressed as percentage of incorporation above control (mean \pm S.E.M. of three independent experiments performed in triplicate). Incorporation of [methyl- ${ }^{3} \mathrm{H}$ ] thymidine in the control was $1441 \pm 164$ d.p.m./well. ${ }^{*} P<0.05$ compared to control, Student's $t$-test.

a significant increase in $\mathrm{Mmp} 7$ transcripts after treatment with $100 \mathrm{ng} / \mathrm{ml}$ relaxin $(P<0.02 ; N=3$; Fig. $6 \mathrm{~A})$, but no significant changes were observed in $\mathrm{Mmp2}(\mathrm{N}=4)$ and Mmp9 $(N=5)$, even with shorter $(30 \mathrm{~min})$ or longer (240 min) incubation periods, and higher relaxin concentration $(500 \mathrm{ng} / \mathrm{ml}$; not shown). As relaxin is known to increase nitric oxide $(\mathrm{NO})$ production in several tissues (Dschietzig et al. 2006), we tested its effect on the inducible nitric oxide synthase 2 (Nos2) of the vas deferens. Relaxin caused a significant increase in the mRNA levels for Nos2 $(P<0.05, N=5$, Fig. 6A).

Relaxin affects expression of estrogen receptors in several tissues (Pillai et al. 2002, Siebel et al. 2003, Yan et al. 2008), but in vitro treatment of the vas deferens with $100 \mathrm{ng} / \mathrm{ml}$ relaxin did not significantly change the levels of transcripts for the estrogen receptors Esr1, Esr2, and Gper (Fig. 6B). Shorter and longer incubation periods (30 and $240 \mathrm{~min}$ ) also failed to alter estrogen receptor transcript levels (not shown). Relaxin tended to down-regulate the mRNA level of its own receptor, but this effect was not statistically significant (Fig. 6B).

\section{Regulation of the gene transcription for relaxin and its receptor (Rxfp1)}

Although the mRNA levels for Rxfp1 in testis were not different between 15- and 120-day-old rats, levels of relaxin transcripts in the testis from adult 120-day-old rats were much lower than in testis from immature 15-day-old rats (Fig. 7A). This prompted us to investigate the role of steroid hormones on the regulation of relaxin and relaxin receptor $R x f p 1$ gene expression. As shown in Fig. 7B, 15 days after castration, expression of the relaxin gene in the prostate was abolished, and it was significantly reduced in the vas deferens. The inhibition of relaxin gene expression caused by castration was completely prevented by supplementation with testosterone. On the other hand, treatment of the animals with the estrogen receptor antagonist ICI 182,780 did not change the relaxin gene expression in the prostate (control $=0.8 \pm 0.1 ; \mathrm{ICl}=0.7 \pm 0.4 ; N=3$ ) or in the vas deferens (control $=1.0 \pm 0.2 ; \mathrm{ICl}=0.9 \pm 0.1 ; N=3$ ).

We also investigated whether castration, which drastically reduces the mRNA levels of relaxin, affects the mRNA levels of the relaxin receptor. Neither castration nor treatment with testosterone affected the Rxfp1 mRNA levels (Fig. 7B). Blockade of the action of estrogen by treatment with the estrogen receptor antagonist $\mathrm{ICI} 182,780$ did not cause any significant changes in Rxfp1 gene transcription (not shown).

\section{Discussion}

The present study provides evidence that relaxin in the male reproductive tract of the rat is not only produced by the prostate, but low levels of the hormone are also synthesized by the testis and the vas deferens. The lower levels of the relaxin mRNA in testis and vas deferens compared with prostate contrast with the higher levels of the relaxin receptor Rxfp1 mRNA previously found in those tissues (Filonzi et al. 2007). Locally produced relaxin may affect in an autocrine or paracrine way processes such as proliferation, fluid secretion, and NO synthesis.
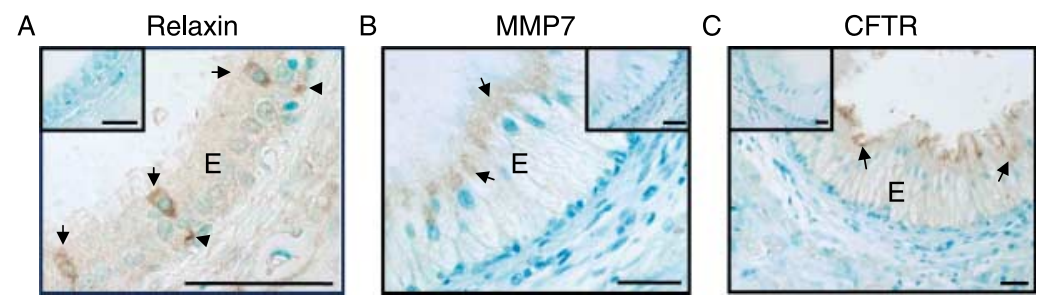

Figure 5 Immunohistochemical localization of relaxin, metalloproteinase 7, and CFTR in the vas deferens of 120-day-old rats. (A) Relaxin-specific immunoreaction with the anti-rat relaxin 1 antibody (ab 70803, Abcam) was observed in the apical cells (arrows) of the epithelium of the proximal vas deferens and lower levels in the basal portion of the epithelial layer (arrow heads). (B) MMP7-specific immunoreactivity in the supranuclear region of the epithelial cells (arrows) in a cross section of the distal region of the vas deferens. (C) CFTR-specific immunoreactivity in the apical region of the epithelial cells and in microvilli (arrows), in a cross section of the distal vas deferens. Representative examples of three different analyses. Insets show negative controls incubated in the absence of the primary antibody. Scale bars are $10 \mu \mathrm{m}$. 

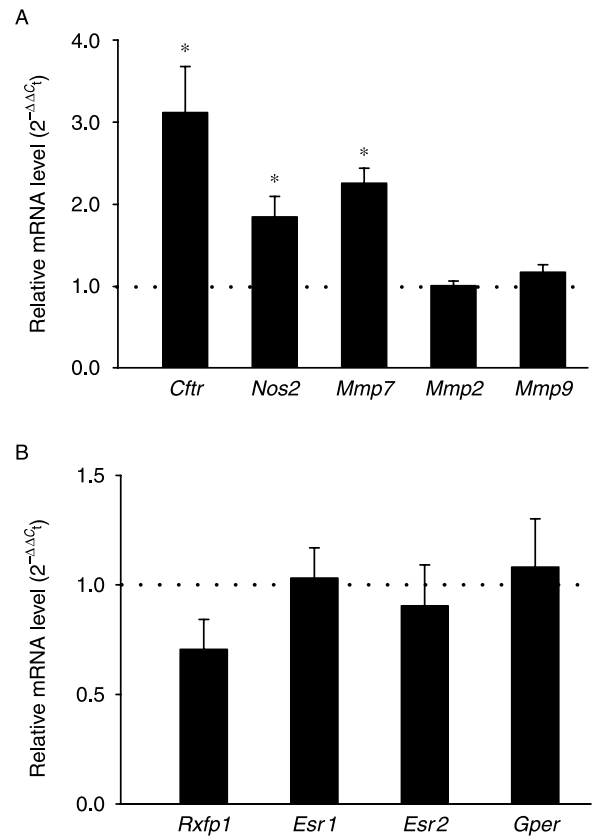

Figure 6 Real-time PCR analysis of the effect of relaxin on gene transcription in the vas deferens of 120-day-old rats. (A) Relative mRNA levels of Cftr, Nos2, Mmp7, Mmp2, and Mmp9; (B) relative mRNA levels of relaxin (Rxfp1) and estrogen receptors (Esr1, Esr2, and Gper). One vas deferens from each rat was incubated for $120 \mathrm{~min}$ at $35^{\circ} \mathrm{C}$ with $100 \mathrm{ng} / \mathrm{ml}$ relaxin, and the contralateral was incubated in the absence of relaxin (control). Values were normalized with $\beta$-actin expression. Control value $(=1)$ is indicated by dotted lines. Results are means \pm s.E.M. of three to five independent experiments performed in triplicate. ${ }^{*} P<0.05$ compared to control (Student's $t$-test).

Relaxin is a $6 \mathrm{kDa}$ peptide that is produced in a way similar to insulin from a preprohormone (for review, see Dschietzig et al. (2006)). There is evidence that the relaxin precursors are as active as the mature peptide (Soloff et al. 1992, Zarreh-Hoshyari-Khah et al. 2001). In the present study, molecular forms that may correspond to relaxin precursors were detected by western blot analysis in the ovary, prostate, testis, and vas deferens, but the mature relaxin peptide could be detected only in the prostate, suggesting levels of mature relaxin were below the detection limit in the other tissues. Novak et al. (2006) detected the mature peptide in the ovary of rats from late pregnancy. The difference with our result may be due to differences in the ability of the antibodies to detect low levels of the hormone or to differences in the stage of pregnancy. Levels of relaxin precursors are 30 times higher than that of the mature protein on day 20 of the pregnancy, but they decline sharply by the end of pregnancy (Crish et al. 1986, Soloff et al. 1992).

The variation in relaxin and relaxin precursor ratios in different tissues suggests that the mechanism or the rate of processing of preprorelaxin can vary. It remains to be determined whether the prominent $16 \mathrm{kDa}$ band in the vas deferens corresponds to the $16 \mathrm{kDa}$ prorelaxin described by others (Soloff et al. 1992). If this is the case, the vas deferens would offer an opportunity for the study of the processing and function of this relaxin precursor.

The levels of relaxin gene expression in the various target tissues are always very low, and subjected to regulation at transcriptional and post-transcriptional levels (Garibay-Tupas et al. 2004). This tight regulation seems to be characteristic of many genes that encode hormones with autocrine and paracrine roles. The factors that regulate the relaxin gene are not completely clear. In the rat ovary, estrogen is a main regulator of relaxin gene expression and dihydrotestosterone does not have any effect (Crish et al. 1986), but the effect of estrogen may be indirect (Sherwood et al. 1986, Peters et al. 2000). Other steroid hormones, such as progesterone and glucocorticoids, seem to regulate relaxin gene expression via binding to a response element on the $5^{\prime}$-flanking region of the relaxin genes
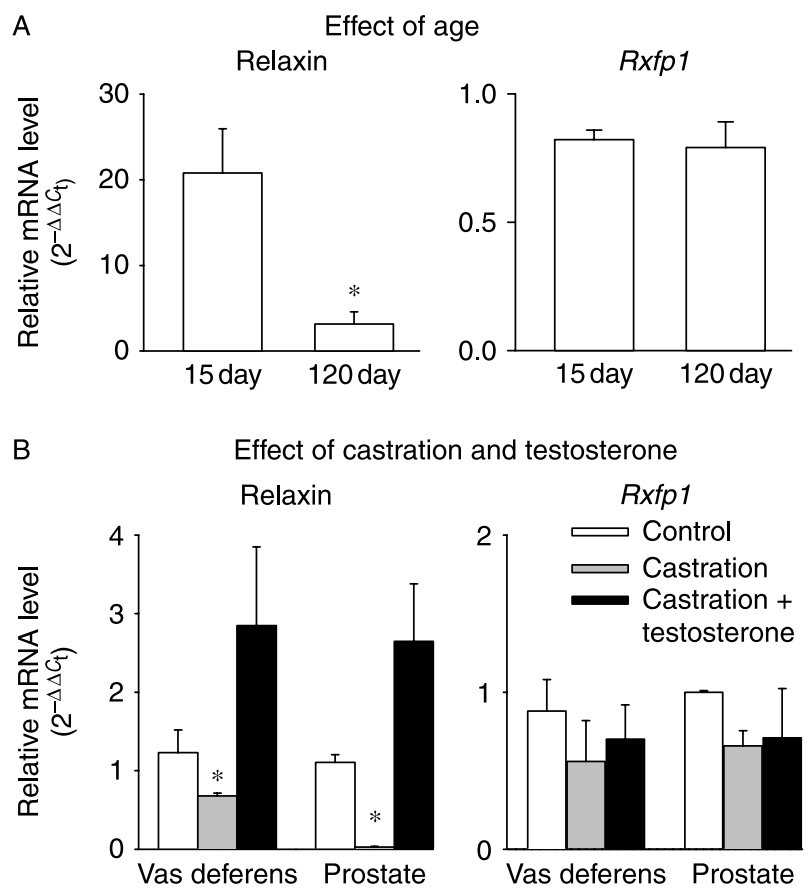

Figure 7 Real-time PCR analysis of the regulation of relaxin and relaxin receptor Rxfp1 gene expression. (A) Level of relaxin and Rxfp1 transcripts in the testis of 15- and 120-day-old rats. Values were normalized with $\beta$-actin expression using vas deferens of 120-day-old animals as a calibrator of the experiment (means \pm s.E.M. of three independent experiments performed in triplicate). (B) Effect of castration and supplementation with testosterone on expression of relaxin and Rxfp 1 in vas deferens and prostate of adult rats. Controls were sham operated; castrated rats were castrated 15 days before killing and immediately treated with either vehicle or testosterone. Values were normalized with $\beta$-actin expression, and are expressed as relative values using one of the controls of each tissue as a calibrator of the experiment (means \pm s.E.M. of three independent experiments performed in triplicate). ${ }^{*} P<0.05$ compared to other values (Newman-Keuls test). 
(Garibay-Tupas et al. 2004). Relaxin also regulates its own gene expression through the binding of relaxinactivated glucocorticoid receptor to the promoter region of the human relaxin-2 gene (Dschietzig et al. 2009).

Our finding that castration reduced relaxin gene expression in the prostate and vas deferens, and the reversal of these effects by administration of testosterone, suggests that testosterone is an important regulator of relaxin gene expression in the reproductive tract of the male rat. In accordance with our results, De Rienzo et al. (2006) found that testosterone increased the relaxin mRNA levels in frog Leydig cells. However, the effect of testosterone on relaxin gene expression seems cell type dependent. Dihydrotestosterone does not affect the production of relaxin mRNA in the rat ovary (Crish et al. 1986), and in the prostate cancer cell line LNCaP, androgens inhibit production of relaxin mRNA (Thompson et al. 2006). In another prostate cancer cell line, PC-3, androgens positively regulate the relaxin promoter (Brookes et al. 1998). Nevertheless, our observation that relaxin mRNA levels in the testis were much higher in immature than in mature rats corroborates the suggestion of De Rienzo et al. (2006) that relaxin gene expression depends on additional factors.

The expression of the relaxin receptor $R x f p 1$ gene in prostate and vas deferens does not seem to be regulated either by testosterone or by estrogen, because castration and treatment with the anti-estrogen ICI 182,780 did not affect Rxfp1 expression. Furthermore, whereas others described an increase in uterine $R \times f p 1$ mRNA levels after estrogen treatment (Yan et al. 2008), we did not observe any changes in mRNA levels for relaxin or $R x f p 1$ after $\mathrm{ICI}$ 182,780 treatment. One might consider that estrogen could regulate the relaxin or Rxfp1 mRNA levels through a mechanism involving the more recently described estrogen G-protein coupled receptor, GPER (Filardo 2002, Revankar et al. 2005). This does not seem to happen because ICI 182,780 acts as an agonist on GPER (Thomas et al. 2005), and we should therefore expect an increase in relaxin and $R x f p 1 \mathrm{mRNA}$ levels.

Although relaxin regulates Esr1 and Esr2 expression in the female tract, it failed to affect expression of Esr1 and Esr2 and the G protein-coupled estrogen receptor GPR30 (Gper) in the vas deferens. Relaxin is also known to reduce mRNA levels of the $R \times f p 1$ receptor in the cervix (Yan et al. 2008), and our results show a similar trend in the vas deferens.

We have previously shown that the relaxin receptor RXFP1 is expressed in Sertoli cells (Filonzi et al. 2007). In the present study, we demonstrated that Sertoli cells represent an important source of relaxin gene expression in the testis, suggesting an autocrine role of relaxin in Sertoli cells. The high levels of relaxin mRNA and protein in the testis of 15-day-old animals suggest that relaxin plays a role in early phases of development. The immunohistochemical studies, showing relaxin immunoreactivity in Sertoli cells of immature animals, and the proliferative effect of relaxin on these cells corroborate this idea. The demonstration that relaxin stimulates proliferation in cultured Sertoli cells is in line with previous reports that relaxin stimulates cell proliferation in granulosa and theca cells (Bagnell et al. 1993, Zhang \& Bagnell 1993, Ohleth \& Bagnell 1995), endometrium (Masters et al. 2007), and cervix (Lee et al. 2005). The number of Sertoli cells in the adult testis determines testis size and daily sperm production. Whereas relaxin may indirectly affect spermatogenesis in the adult through stimulation of Sertoli cell proliferation, relaxin may also directly affect spermatogenesis, because relaxin was present in pachytene spermatocytes, suggesting a role in meiosis. Relaxin was also present in spermatids, and may act on relaxin receptors in elongating spermatids (Filonzi et al. 2007). In conclusion, relaxin may play a more comprehensive role in spermatogenesis and spermiogenesis.

Although relaxin receptors are present in the muscular layer of the vas deferens, relaxin does not alter the contractility of the organ (Filonzi et al. 2007). Relaxin receptors were also detected in the epithelial layer of the vas deferens. It is particularly interesting to note that relaxin is expressed in the apical cells of the vas deferens epithelium, suggesting a role in secretion and composition of the seminal plasma. The apical cells in the vas deferens are a distinct population of epithelial cells that co-express high levels of $\mathrm{H}^{+}$-ATPase on the luminal plasma membrane and carbonic anhydrase II in the cytoplasm (Brown et al. 1992, Breton et al. 1996, 1999). These two proteins are important for transepithelial proton translocation (Brown \& Breton 2000). Furthermore, relaxin caused a discrete increase in the mRNA levels for Cftr. CFTR allows $\mathrm{Cl}^{-}$efflux to the lumen and modulates fluid transport, but also affects bicarbonate secretion, and therefore affects sperm-fertilizing capacity and male fertility (Chan et al. 2006, Xu et al. 2007). Mutations in this gene not only cause the cystic fibrosis syndrome (Quinton 1990, Van der Ven et al. 1996, Rowe et al. 2005), but also the bilateral absence of the vas deferens. However, the presence of CFTR in the vas deferens has been controversial. Using in situ hybridization, Trezise et al. (1993) did not detect Cftr mRNA in the rat vas deferens, whereas Patrizio \& Salameh (1998) reported a strong signal in the human vas deferens. Pietrement et al. (2008) reported that CFTR co-localized with aquaporin 9 and NHERF1 in the apical membrane of rat epididymis and vas deferens, but they only show results for the epididymis. In the present study, we detected immunoreactivity to CFTR in the epithelial layer of the vas deferens, especially close to the apical membrane and in some microvilli.

The role of relaxin in the regulation of metalloproteinase expression and activity is well known, and it is thought that the fibrosis induced by relaxin knockout is due to changes in metalloproteinase activity (Samuel et al. 2003b, 2005). We found previously that relaxin 
stimulates $M m p 7$ gene expression in the vas deferens (Filonzi et al. 2007), and we now show that this effect is selective to Mmp7, because the mRNA levels for Mmp2 and $M m p 9$ remained unchanged after relaxin treatment. MMP7 presents a broad spectrum of actions (reviewed in li et al. (2006)), including a role in apoptosis, cell proliferation, and release of growth factors. In the male reproductive tract, it has been demonstrated that MMP7 is important for testicular integrity and fertility (Rudolph-Owen et al. 1998), and it is present in human semen (Riccioli et al. 2005). Our immunohistochemical studies show that MMP7 expression is expressed only in epithelial cells of the vas deferens. Therefore, it seems likely that MMP7 produced in the epithelium of the vas deferens is released to the lumen to affect spermatozoa. Whether MMP7 is also released to the basolateral compartment to participate in tissue remodeling is not clear.

The mechanism of relaxin action in the testis and vas deferens remains to be determined. Relaxin has been shown to up-regulate the inducible form of Nos2 in MCF-7 breast adenocarcinoma cells (Bani 1997) and in endothelial cells from human umbilical vein (Quattrone et al. 2004). On the other hand, relaxin up-regulates the endothelial-type NOS but not Nos2 in mouse myometrium (Bani et al. 1999). In the present study, we found that relaxin increased the Nos2 mRNA in the vas deferens, suggesting that NO may play a role in the relaxin action in this organ, and that relaxin may contribute to the NOS activity found in seminal plasma. In the male reproductive tract, $\mathrm{NO}$ probably plays an important role in several aspects of testicular function, including spermatogenesis and sperm maturation (Zini et al. 1996). NOS has been localized in the reproductive organs of the male rat, and the highest levels of NOS activity were present in the caudal segment of the epididymis and in the vas deferens (Burnett et al. 1995, Zini et al. 1996). NOS activity has also been detected in human seminal plasma, it may affect sperm function, and it is interesting to note that men without detectable NOS in sperm presented bilateral absence of the vas deferens (Zini et al. 2001).

In conclusion, we have shown that relaxin is produced by the testis and vas deferens, where it may affect proliferation of Sertoli cells and gene expression. Both tissues co-express relaxin and its receptor, suggesting that relaxin plays an autocrine/paracrine role in the male reproductive tract.

\section{Materials and Methods}

\section{Hormones}

Porcine relaxin and human $\mathrm{FSH}(\mathrm{hFSH})$ were obtained from Dr A F Parlow, from the National Hormone Peptide Program (Torrance, CA, USA).

\section{Animals}

Wistar rats were housed in the Animal Facility of the Instituto Nacional de Farmacologia e Biologia Molecular, UNIFESPEPM, and maintained on a $12 \mathrm{~h}$ light:12 h darkness schedule, at $23{ }^{\circ} \mathrm{C}$, with food and water freely available. All procedures were approved by the Institutional Research Ethics Committee (protocol 1657/07).

\section{In vivo treatments}

\section{Anti-estrogen treatment}

Animals were treated as previously described (Oliveira et al. 2002, Yasuhara et al. 2008). Rats were treated once a week for 2 months with corn oil (control group) or ICI 182,780 (10 mg/ rat, s.c., AstraZeneca), starting at an age of 30 days. This treatment does not alter plasma estradiol and testosterone (Yasuhara et al. 2008).

\section{Castration}

Ninety-day-old rats were anesthetized with sodium pentobarbital $(30 \mathrm{mg} / \mathrm{kg})$ and the testes were removed. Some castrated rats were given weekly s.c. injections of $25 \mathrm{mg}$ testosterone (Durateston 250, Organon, São Paulo, Brazil), starting on the day of castration. Fifteen days after castration, animals were killed by decapitation and the prostate and vas deferens were removed.

\section{In vitro treatments with relaxin}

To analyze the effects of relaxin on gene expression, the vas deferens was removed from 120-day-old rats, dissected free from fat and connective tissues, and rinsed with $\mathrm{PBS}(137 \mathrm{mM}$; $\mathrm{NaCl}, 2.68 \mathrm{mM}$; KCl, $6.03 \mathrm{mM}$; $\mathrm{Na}_{2} \mathrm{HPO}_{4}, 1.47 \mathrm{mM} ; \mathrm{KH}_{2} \mathrm{PO}_{4}$, $\mathrm{pH}$ 7.4). To increase contact of the hormone with the lumen, the vas deferens was opened and cut into four pieces. The tissues were transferred to a 6 -well plate containing phenol redfree Ham's F12/DMEM 1:1 (Gibco, Invitrogen), $\mathrm{pH} 7.2-7.4$, and incubated in a humidified atmosphere of $5 \% \mathrm{CO}_{2}-95 \%$ air at $35{ }^{\circ} \mathrm{C}$. After equilibration for $15 \mathrm{~min}$, one duct was incubated with $100 \mathrm{ng} / \mathrm{ml}$ relaxin, and the contralateral duct with PBS, for 30,60 , or $240 \mathrm{~min}$. Stimulation was stopped by cooling to $0^{\circ} \mathrm{C}$, and the total RNA was extracted from the tissues.

\section{Primary cultures of Sertoli cells}

The testes from 15-day-old rats were removed and decapsulated, and Sertoli cells were isolated (Lucas et al. 2004, 2008). Aliquots of $1 \mathrm{ml}$ of the cell suspension were plated in 12-well plates at a density of $\sim 4 \times 10^{4}$ cells/well (about 10000 cells/ $\mathrm{cm}^{2}$ ) in phenol red-free F12/DMEM containing $0.02 \mathrm{~g} / \mathrm{l}$ gentamicin (Sigma Chemical Co.), $\mathrm{pH} 7.2-7.4$, supplemented with $10 \mu \mathrm{g} / \mathrm{ml}$ insulin, $10 \mu \mathrm{g} / \mathrm{ml}$ transferrin, $10 \mathrm{ng} / \mathrm{ml}$ sodium selenite, and $10 \mathrm{ng} / \mathrm{ml}$ epidermal growth factor (Sigma). The cells were grown for $48 \mathrm{~h}$ in a humidified atmosphere of $5 \%$ $\mathrm{CO}_{2}-95 \%$ air at $35{ }^{\circ} \mathrm{C}$, treated with $20 \mathrm{mM}$ Tris- $\mathrm{HCl}(\mathrm{pH} 7.4)$ to lyse residual germ cells (Galdieri et al. 1981), and allowed to grow for another $24 \mathrm{~h}$. The culture medium was replaced by 
one without supplements $20 \mathrm{~h}$ before the experiments. At this stage, the cells were $50-60 \%$ confluent, and viability, as determined by trypan blue exclusion, was more than $90 \%$. The characterization of the culture was described elsewhere (Lucas et al. 2008).

\section{Immunohistochemistry}

Tissues from immature (15-day-old) or from adult rats (120-dayold males or females around the 21st day of pregnancy) were removed, fixed in Bouin, and embedded in paraffin. Sections of 5-7 $\mu \mathrm{m}$ thickness were cut and mounted on silanized slides (Dako, Carpinteria, CA, USA). Immunoperoxidase reaction was performed as previously described (Yasuhara et al. 2008). Briefly, tissue sections were incubated for $5 \mathrm{~min}$ at room temperature with $0.1 \mathrm{M}$ glycine in Tris-buffered saline (TBS, $20 \mathrm{mM}$ Tris- $\mathrm{HCl}, 150 \mathrm{mM} \mathrm{NaCl}, \mathrm{pH}$ 7.4). Nonspecific antibody binding was minimized by incubation with blocking solution: TBS containing 5-10\% BSA (for relaxin and CFTR) or $10 \%$ rabbit serum (for $\mathrm{MMP} 7$ ) for $15 \mathrm{~min}$ at $37^{\circ} \mathrm{C}$ in a humidified chamber. Slides were then incubated with the appropriate primary antibody: 1) an overnight incubation at $4{ }^{\circ} \mathrm{C}$ with 1:50-1:500 dilution of a goat polyclonal antibody raised against the $\mathrm{N}$-terminal region of human relaxin $(\mathrm{N}-18$, Santa Cruz Biotechnology), which recognizes the relaxin mature peptide and its precursor; 2) $2 \mathrm{~h}$ incubation at $37^{\circ} \mathrm{C}$ with 1:100 dilution of a rabbit polyclonal antibody against a region surrounding amino acid 130 of the rat relaxin 1 (ab70803, Abcam), which recognizes only relaxin precursors but not the mature peptide; 3) $2 \mathrm{~h}$ incubation at $35-37^{\circ} \mathrm{C}$ with a 1:100 dilution of a goat polyclonal antibody raised against a peptide mapping near the $\mathrm{N}$-terminal region of human CFTR (N-20, Santa Cruz Biotechnology; 4) $2 \mathrm{~h}$ incubation at $37^{\circ} \mathrm{C}$ with 1:80 dilution of a goat polyclonal antibody raised against a peptide mapping near the C-terminus of human MMP7 (C-17, Santa Cruz Biotechnology). The sections were washed with TBS containing $0.1 \%$ Tween 20 (TBS-T), incubated with blocking solution for another $15 \mathrm{~min}$, and then incubated with the appropriate secondary antibody, conjugated to HRP (1:250 rabbit anti-goat, Jackson ImmunoResearch, West Grove, PA, USA or 1:100 donkey anti-rabbit, GE, Piscataway, NJ, USA) for $30 \mathrm{~min}$ at $37^{\circ} \mathrm{C}$. Negative control slides were developed in the absence of the primary antibody. The stained sections were visualized with a Nikon E800 microscope (Nikon, Melville, NY, USA). Images were captured with a CooISNAP-Pro CCD digital camera and processed with Image-Pro Express Software (Media Cybernetics, Silver Spring, MD, USA).

\section{Western blot for detection of relaxin}

Testis, vas deferens, and prostate from 120-day-old rats and ovaries from rats in the 21 st day of pregnancy were isolated, frozen immediately in liquid nitrogen, and pulverized in a tissue grinder. The pulverized tissues were homogenized with a Polytron homogenizer in ice-cold lysis buffer $(50 \mathrm{mM}$ Hepes, $\mathrm{pH} 7.5,5 \mathrm{M} \mathrm{NaCl}, 10 \%$ glycerol, $1 \%$ Triton $\mathrm{X}-100$, and $10 \mathrm{mM}$ EGTA), in the presence of protease inhibitors ( $1 \mu \mathrm{g} / \mathrm{ml}$ leupeptine, $1 \mu \mathrm{g} / \mathrm{ml}$ aprotinin, and $1 \mathrm{mM}$ phenylmethylsulfonyl fluoride). The lysates were centrifuged at $11200 \mathrm{~g}$ for $30 \mathrm{~min}$ at $4{ }^{\circ} \mathrm{C}$.
Protein content of the supernatant was determined with the Bio-Rad protein assay and a BSA standard (Bio-Rad Laboratories).

Proteins from supernatant $(100 \mu \mathrm{g} /$ lane) were incubated with sample buffer containing dithiothreitol and $\beta$-mercaptoethanol, and subjected to $15 \%$ SDS/PAGE. Proteins were electrotransferred overnight $\left(20 \mathrm{~V}\right.$ at $\left.4{ }^{\circ} \mathrm{C}\right)$ to PVDF membranes $(0.45 \mu \mathrm{m}$ pore size, ImmobilonP, Millipore, Bedford, MA, USA). Membranes were blocked for $2 \mathrm{~h}$ at room temperature in TBS (10 mM Tris, $150 \mathrm{mM} \mathrm{NaCl}, \mathrm{pH}$ 8.0) containing 0.2\% Tween 20 and $5 \%$ nonfat dry milk. The membranes were incubated with anti-relaxin antibody N18 (Santa Cruz Biotechnologies) diluted 1:100 in blocking solution for $16 \mathrm{~h}$ at $4{ }^{\circ} \mathrm{C}$. This antibody was chosen after immunohistochemical studies showed its ability to detect immunoreactivity in the ovary of pregnant rats and in the rat prostate (see Results). Membranes were washed in TBS-T, incubated for $1 \mathrm{~h}$ at room temperature with a 1:20 000 dilution of secondary antibody (rabbit anti-goat HRP-conjugated anti-IgG, Jackson Immunoresearch Lab.), and washed again with TBS-T. Immunoreactive bands were visualized on preflashed Biomax XAR film (Eastman Kodak Co.) by ECL reagent (Luminol, PerkinElmer, Boston, MA, USA). In negative controls, primary antibody was pre-incubated for $16 \mathrm{~h}$ at $4{ }^{\circ} \mathrm{C}$ with the lysate from ovaries of 21-day pregnant rats, and processed as described above. Apparent molecular weights of protein bands were determined from molecular weight standards (prestained protein marker, broad range 6-175 kDa, New England Biolabs, Boston, MA, USA).

\section{[Methyl- ${ }^{3} \mathrm{H}$ ] thymidine incorporation assays}

Incorporation of $\left[\right.$ methyl- $\left.{ }^{3} \mathrm{H}\right]$ thymidine into cell DNA was measured as described by Guizzetti et al. (1996). Previous studies in our laboratory indicated that incorporation of [methyl- ${ }^{3} \mathrm{H}$ ] thymidine $(2 \mu \mathrm{Ci} / \mathrm{ml}$, specific activity $79.0 \mathrm{Ci} /$ mmol, Amersham Biosciences) in cultured Sertoli cells increased linearly between 2 and $10 \mathrm{~h}$ of incubation. All studies were performed using $6 \mathrm{~h}$ of [methyl- ${ }^{3} \mathrm{H}$ ] thymidine incubation (Lucas et al. 2004).

Primary Sertoli cell cultures were initially incubated with $2 \mu \mathrm{Ci} / \mathrm{ml}$ [methyl ${ }^{3} \mathrm{H}$ ] thymidine for $6 \mathrm{~h}$ at $35^{\circ} \mathrm{C}$. Incubation was continued in the absence (control incorporation) and presence of relaxin (100 and $200 \mathrm{ng} / \mathrm{ml}), \mathrm{hFSH}(50 \mathrm{ng} / \mathrm{ml})$, or relaxin and $\mathrm{hFSH}$ (100 and $50 \mathrm{ng} / \mathrm{ml}$ respectively) for $24 \mathrm{~h}$ at $35{ }^{\circ} \mathrm{C}$. The reaction was stopped by cooling the cells at $0{ }^{\circ} \mathrm{C}$. The medium was aspirated, and the cells were rinsed twice with ice-cold PBS and 5\% trichloroacetic acid (Sigma). The cells were then solubilized with $0.5 \mathrm{~N} \mathrm{NaOH}$, collected with cotton swabs, and transferred to $5 \mathrm{ml}$ OptiPhase HiSafe 3 scintillation liquid (PerkinElmer Life Science Products). Bound radioactivity was determined in scintillation $\beta$ counter (LS 6000 IC, Beckman Coulter Inc., Palo Alto, CA, USA). Results were expressed as percentage of [methyl- ${ }^{3} \mathrm{H}$ ] thymidine incorporation above control.

\section{Real-time qRT-PCR}

The mRNA levels for the following genes were analyzed by quantitative real-time PCR: relaxin $(R \ln 1)$; the cystic fibrosis chloride channel (Cftr); Mmp2, Mmp7, and 
Table 1 Oligonucleotides used in the real-time PCR.

\begin{tabular}{|c|c|c|c|}
\hline Transcript (accession number) & Orientation & Sequence $\left(5^{\prime} \rightarrow 3^{\prime}\right)$ & Nucleotide position \\
\hline Actb & Forward & GTA GCC ATC CAG GCT GTG TT & $481-500$ \\
\hline NM_031144.2 & Reverse & CCC TCA TAG ATG GGC ACA GT & 584-565 \\
\hline$R \ln 1$ (relaxin) & Forward & AGG AGT GGA TGG ACC AAG TC & $120-139$ \\
\hline NM_013413.1 & Reverse & ATG GCA CAA CTT CTG CAG TG & $269-250$ \\
\hline Mmp7 & Forward & CAC GGA GAC AAC TTC CCA TT & $515-534$ \\
\hline NM_012864.2 & Reverse & CAC CAT CCG TCC AGT ACT CA & $632-613$ \\
\hline $\mathrm{Cftr}^{-}$ & Forward & TGG AGG TGA AAT GGT TGT CA & $3743-3762$ \\
\hline NM_031506.1 & Reverse & ACC CTC TGG CCA GGA CTT AT & $3844-3825$ \\
\hline Esri & Forward & CCA TAT CCG GCA CAT GAG TA & $1760-1779$ \\
\hline NM_012689.1 & Reverse & TGA AGA CGA TGA GCA TCC AG & 1873-1854 \\
\hline Esr2 ${ }^{-}$ & Forward & CTC ACG TCA GGC ACA TCA GT & 1669-1688 \\
\hline NM_012754.1 & Reverse & TGT GAG CAT TCA GCA TCT CC & $1776-1757$ \\
\hline Gper & Forward & CCC TTG ACA GGC CAC ATA GT & $952-971$ \\
\hline NM_133573.1 & Reverse & СTC CGT GCT GTC TGG TAT GA & $1140-1121$ \\
\hline Rxfp1 & Forward & TGA GGC AGA AAC TTC CGA AT & 264-283 \\
\hline NM_201417.1 & Reverse & TCC ATT GCA GGG ACA TTA CA & $406-387$ \\
\hline Nos2 & Forward & CCT GTG TTC CAC CAG GAG AT & $1601-1620$ \\
\hline NM_012611.3 & Reverse & CGC TTT CAC CAA GAC TGT GA & $1744-1725$ \\
\hline
\end{tabular}

Mmp9; the inducible form of Nos2; the estrogen receptors $\alpha$ (Esr1), $\beta$ (Esr2), and GPR30 (Gper); and the relaxin receptor Rxfp1.

\section{RNA extraction and CDNA synthesis}

Total RNA was extracted with the TRIzol reagent (Invitrogen) according to the standard protocol (Chomczynski \& Sacchi 1987). RNA was further treated with RNase-free DNase I (Qiagen) to eliminate genomic DNA contamination, and purified using the RNeasy Mini Kit (Qiagen) according to instructions of the manufacturer. RNA concentration was measured by u.v. spectrophotometry, and OD 260:280 nm ratios between 1.8 and 2.1 were obtained for all RNA samples. Ribosomal RNA integrity was checked on agarose gel electrophoresis, and a sharp and clear 2:1 ratio of ethidium bromidestained 28S:18S rRNA bands was observed for all samples.

Two micrograms total RNA were used to synthesize the first strand CDNA at $50{ }^{\circ} \mathrm{C}$ with the Superscript III first strand synthesis Supermix (Invitrogen) and the oligo-dT primer supplied with this kit.

\section{Quantitative PCR}

For the qPCR, we used the SYBR Green system (Applied Biosystems, Foster City, CA, USA). The primers (Invitrogen) were designed with the Primer3 program (Rozen \& Skaletsky 2000) and spanned exon-exon boundaries whenever possible (Table 1). $\beta$-Actin (Actb) was used as an endogenous control and to normalize cDNA amount and PCR efficiency. Primers for all target genes and for $\beta$-actin were designed to have approximately the same amplification efficiency $(=1)$. Efficiency was calculated based on the amplification curves obtained with five cDNA concentrations $(0.01,0.1,1,10$, and $100 \mathrm{ng} / \mathrm{ml})$. The slope of the amplification curves $C_{\mathrm{t}} \times \log (\mathrm{cDNA})$ was calculated. The efficiency value was calculated from the equation:

$E=10^{(-1 / \text { slope })}-1$.

Controls without cDNA or without primers were included in each assay. Samples were run in an ABI PRISM 7500 Sequence
Detection System (Applied Biosystems) using default conditions of amplification $\left(50{ }^{\circ} \mathrm{C}\right.$ for $2 \mathrm{~min}, 95^{\circ} \mathrm{C}$ for $10 \mathrm{~min}$, and 40 cycles of $95{ }^{\circ} \mathrm{C}$ for $15 \mathrm{~s}$ and $60{ }^{\circ} \mathrm{C}$ for $1 \mathrm{~min}$ ). The dissociation curves were obtained at the end of the amplification to confirm specificity of the amplification. Each sample was run in triplicate. The average cycle threshold $\left(C_{t}\right)$ was determined with Applied Biosystems software. The mean \pm s.E.M. of $C_{t}$ values for the endogenous control, $\beta$-actin, was $15.9 \pm 0.1(N=40)$. The $C_{t}$ values for the targets $(N=3-6)$ were as follows: $R \ln 1$ in prostate, $27.2 \pm 0.2 R \ln 1$ in testis of 120 -day-old animals, $31.6 \pm 0.3 R \ln 1$ in vas deferens, $31.3 \pm 0.5 ; R \ln 1$ in testis of 15 -day-old animals, $28.1 \pm 0.2 ; R \ln 1$ in Sertoli cells, 28.2 $\pm 0.6 ;$ Cftr, $30.0 \pm 0.7$; Mmp7, 24.5 $\pm 0.6 ;$ Mmp2, 18.0 $\pm 0.1 ; M m p 9,15.1 \pm 0.1 ; E s r 1$,

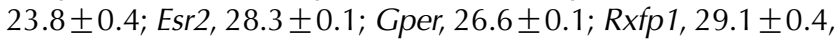
and Nos2, 27.7 \pm 0.9 . Data were analyzed by the comparative $\Delta \Delta C_{\mathrm{t}}$ method (ABI PRISM User Bulletin \#2, Applied Biosystems). The control values were always used as a calibrator in each experiment, except in the experiments to compare expression levels of relaxin in different tissues, and relaxin expression in testis of 15- and 120-day-old rats, where the calibrator was the value obtained with the vas deferens. Data are expressed as mean \pm S.E.M. of the $2^{-\Delta \Delta C_{\mathrm{t}}}$ from three to five different cDNAs (from three to five different animals). At the end of the experiments, samples were run in $2 \%$ agarose gel electrophoresis to further confirm the absence of nonspecific amplification. The size of the expected products was compared to a DNA ladder (100 bp ladder, Invitrogen). Identity of the PCR products was further confirmed by automated DNA sequencing with the DYEnamic ET Terminator Sequencing Kit (Amersham Biosciences).

\section{Statistical analyses}

Data were expressed as mean \pm S.E.M. Statistical analysis was carried out by ANOVA followed by Newman-Keuls test for multiple comparisons or by Student's $t$-test to compare the differences between two data. $P$ values $<0.05$ were accepted as significant. 


\section{Declaration of interest}

The authors declared that there is no conflict of interest that could be perceived as prejudicing the impartiality of the research reported.

\section{Funding}

This study was supported by the Fundação de Amparo à Pesquisa do Estado de São Paulo (FAPESP, grant number 2006/60406-7 to M F M Lazari). C S Porto was supported by a Research fellowship from the Conselho Nacional de Desenvolvimento Cientifico e Tecnológico (CNPq). L C Cardoso was supported by a Master fellowship from the Coordenação de Aperfeiçoamento de Pessoal de Nível Superior (CAPES). A R Nascimento and $C$ Royer were supported by an undergraduate and a doctoral fellowship respectively from $\mathrm{CNPq}$.

\section{Acknowledgements}

We thank Ms Gisele R O Gomes and Mrs Espedita M J Silva Santos for their helpful assistance, and Dr G H M Schoorlemmer for critical revision of this manuscript.

\section{References}

Anderson MB, Collado-Torres M \& Vaupel MR 1986 Absence of relaxin immunostaining in the male reproductive tracts of the rat and mouse. Journal of Histochemistry and Cytochemistry 34 945-948.

Bagnell CA, Zhang Q, Downey B \& Ainsworth L 1993 Sources and biological actions of relaxin in pigs. Journal of Reproduction and Fertility Supplement 48 127-138.

Bani D 1997 Relaxin and breast cancer. Bulletin du Cancer 84 179-182.

Bani D, Baccari MC, Nistri S, Calamai F, Bigazzi M \& Sacchi TB 1999 Relaxin up-regulates the nitric oxide biosynthetic pathway in the mouse uterus: involvement in the inhibition of myometrial contractility. Endocrinology 140 4434-4441.

Breton S, Smith P, Lui B \& Brown D 1996 Acidification of male reproductive tract by a bafilomycin-sensitive H+ATPase. Nature Medicine 2 470-473.

Breton S, Tyszkowski R, Sabolic I \& Brown D 1999 Postnatal development of $\mathrm{H}+$ ATPase (proton-pump)-rich cells in rat epididymis. Histochemistry and Cell Biology 111 97-105.

Brookes DE, Zandvliet D, Watt F, Russell PJ \& Molloy PL 1998 Relative activity and specificity of promoters from prostate-expressed genes. Prostate 35 18-26.

Brown D \& Breton S $2000 \mathrm{H}^{+}$V-ATPase-dependent luminal acidification in the kidney collecting duct and the epididymis/vas deferens: vesicle recycling and transcytotic pathways. Journal of Experimental Biology 203 137-145.

Brown D, Lui B, Gluck S \& Sabolic I 1992 A plasma membrane proton ATPase in specialized cells of rat epididymis. American Journal of Physiology 263 C913-C916.

Burnett AL, Ricker DD, Chamness SL, Maguire MP, Crone JK, Bredt DS, Snyder SH \& Chang TS 1995 Localization of nitric oxide synthase in the reproductive organs of the male rat. Biology of Reproduction 52 1-7.

Chan HC, Shi QX, Zhou CX, Wang XF, Xu WM, Chen WY, Chen AJ, Ni Y \& Yuan YY 2006 Critical role of CFTR in uterine bicarbonate secretion and the fertilizing capacity of sperm. Molecular and Cellular Endocrinology 250 106-113.

Chomczynski P \& Sacchi N 1987 Single-step method of RNA isolation by acid guanidinium thiocyanate-phenol-chloroform extraction. Analytical Biochemistry 162 156-159.

Crish JF, Soloff MS \& Shaw AR 1986 Changes in relaxin precursor mRNA levels in the rat ovary during pregnancy. Journal of Biological Chemistry 61 1909-1913.
De Rienzo G, Aniello F, Branno M, Izzo G \& Minucci S 2006 The expression level of frog relaxin mRNA (fRLX), in the testis of Rana esculenta, is influenced by testosterone. Journal of Experimental Biology 209 3806-3811.

Dschietzig T, Bartsch C, Baumann G \& Stangl K 2006 Relaxin - a pleiotropic hormone and its emerging role for experimental and clinical therapeutics. Pharmacology and Therapeutics 112 38-56.

Dschietzig T, Bartsch C, Wessler S, Baumann G \& Stangl K 2009 Autoregulation of human relaxin-2 gene expression critically involves relaxin and glucocorticoid receptor binding to glucocorticoid response half-sites in the relaxin-2 promoter. Regulatory Peptides 155 163-173.

Dubois MP \& Dacheux JL 1978 Relaxin, a male hormone? Immunocytological localization of a related antigen in the boar testis Cell and Tissue Research 187 201-214.

Einspanier A, Zarreh-Hoshyari-Khah MR, Balvers M, Kerr L, Fuhrmann K \& Ivell $\mathbf{R} 1997$ Local relaxin biosynthesis in the ovary and uterus through the oestrous cycle and early pregnancy in the female marmoset monkey (Callithrix jacchus). Human Reproduction 12 1325-1337.

Filardo EJ 2002 Epidermal growth factor receptor (EGFR) transactivation by estrogen via the G-protein coupled receptor, GPR30: a novel signaling pathway with potential significance for breast cancer. Journal of Steroid Biochemistry and Molecular Biology 80 231-238.

Filonzi M, Cardoso LC, Pimenta MT, Queiróz DB, Avellar MC, Porto CS \& Lazari MF 2007 Relaxin family peptide receptors Rxfp1 and Rxfp2: mapping of the mRNA and protein distribution in the reproductive tract of the male rat. Reproductive Biology and Endocrinology 529.

Galdieri M, Ziparo E, Palombi F, Russo MA \& Stefanini M 1981 Pure Sertoli cells culture: a new model for the study of somatic-germ cell interactions. Journal of Andrology 5 249-259.

Garibay-Tupas JL, Bao S, Kim MT, Tashima LS \& Bryant-Greenwood GD 2000 Isolation and analysis of the $3^{\prime}$-untranslated regions of the human relaxin $\mathrm{H} 1$ and $\mathrm{H} 2$ genes. Journal of Molecular Endocrinology 24 241-252.

Garibay-Tupas JL, Okazaki KJ, Tashima LS, Yamamoto S \& BryantGreenwood GD 2004 Regulation of the human relaxin genes $\mathrm{H} 1$ and $\mathrm{H} 2$ by steroid hormones. Molecular and Cellular Endocrinology 219 $115-125$.

Golos TG, Weyhenmeyer JA \& Sherwood OD 1984 Immunocytochemical localization of relaxin in the ovaries of pregnant rats. Biology of Reproduction 30 257-261.

Guizzetti M, Costa P, Peters J \& Costa LG 1996 Acetylcholine as a mitogen: muscarinic receptor-mediated proliferation of rat astrocytes and human astrocytoma cells. European Journal of Pharmacology 297 265-273.

Gunnersen JM, Crawford RJ \& Tregear GW 1995 Expression of the relaxin gene in rat tissues. Molecular and Cellular Endocrinology 110 55-64.

Gunnersen JM, Fu P, Roche PJ \& Tregear GW 1996 Expression of human relaxin genes: characterization of a novel alternatively-spliced human relaxin mRNA species. Molecular and Cellular Endocrinology 118 85-94.

li M, Yamamoto H, Adachi Y, Maruyama Y \& Shinomura Y 2006 Role of matrix metalloproteinase-7 (matrilysin) in human cancer invasion, apoptosis, growth, and angiogenesis. Experimental Biology and Medicine 231 20-27.

Jeyabalan A, Kerchner LJ, Fisher MC, McGuane JT, Doty KD \& Conrad KP 2006 Matrix metalloproteinase-2 activity, protein, mRNA, and tissue inhibitors in small arteries from pregnant and relaxin-treated nonpregnant rats. Journal of Applied Physiology 100 1955-1963.

Jeyabalan A, Novak J, Doty KD, Matthews J, Fisher MC, Kerchner LJ \& Conrad KP 2007 Vascular matrix metalloproteinase-9 mediates the inhibition of myogenic reactivity in small arteries isolated from rats after short term administration of relaxin. Endocrinology 148 189-197.

Kohsaka T, Takahara H, Sasada H, Kawarasaki T, Bamba K, Masaki J \& Tagami S 1992 Evidence for immunoreactive relaxin in boar seminal vesicles using combined light and electron microscope immunocytochemistry. Journal of Reproduction and Fertility 95 397-408.

Kohsaka T, Hamano K, Sasada H, Watanabe S, Ogine T, Suzuki E, Nishida S, Takahara H \& Sato E 2003 Seminal immunoreactive relaxin in domestic animals and its relationship to sperm motility as a possible index for predicting the fertilizing ability of sires. International Journal of Andrology 26 115-120. 
Lee HY, Zhao S, Fields PA \& Sherwood OD 2005 The extent to which relaxin promotes proliferation and inhibits apoptosis of cervical epithelial and stromal cells is greatest during late pregnancy in rats. Endocrinology 146 511-518.

Lenhart JA, Ryan PL, Ohleth KM, Palmer SS \& Bagnell CA 2001 Relaxin increases secretion of matrix metalloproteinase- 2 and matrix metalloproteinase-9 during uterine and cervical growth and remodeling in the pig. Endocrinology 142 3941-3949.

Leung GP, Gong XD, Cheung KH, Cheng-Chew SB \& Wong PY 2001 Expression of cystic fibrosis transmembrane conductance regulator in rat efferent duct epithelium. Biology of Reproduction 64 1509-1515.

Lucas TF, Avellar MC \& Porto CS 2004 Effects of carbachol on rat Sertoli cell proliferation and muscarinic acetylcholine receptors regulation: an in vitro study. Life Sciences 75 1761-1773.

Lucas TF, Siu ER, Esteves CA, Monteiro HP, Oliveira CA, Porto CS \& Lazari MF $200817 \beta$-Estradiol induces the translocation of the estrogen receptors ESR1 and ESR2 to the cell membrane, MAPK3/1 phosphorylation and proliferation of cultured immature rat Sertoli cells. Biology of Reproduction 78 101-114

Masters RA, Crean BD, Yan W, Moss AG, Ryan PL, Wiley AA, Bagnell CA \& Bartol FF 2007 Neonatal porcine endometrial development and epithelial proliferation affected byage and exposure to estrogen and relaxin. Domestic Animal Endocrinology 33 335-346.

Mookerjee I, Unemori EN, Du XJ, Tregear GW \& Samuel CS 2005 Relaxin modulates fibroblast function, collagen production and matrix metalloproteinase-2 expression by cardiac fibroblasts. Annals of the New York Academy of Sciences 1041 190-193.

Novak J, Parry LJ, Matthews JE, Kerchner LJ, Indovina K, Hanley-Yanez K, Doty KD, Debrah DO, Shroff SG \& Conrad KP 2006 Evidence for local relaxin ligand-receptor expression and function in arteries. FASEB Journal 20 2352-2362.

Ohleth KM \& Bagnell CA 1995 Relaxin-induced deoxyribonucleic acid synthesis in porcine granulosa cells is mediated by insulin-like growth factor-I. Biology of Reproduction 53 1286-1292.

Ohleth KM, Zhang Q \& Bagnell CA 1998 Relaxin protein and gene expression in ovarian follicles of immature pigs. Journal of Molecular Endocrinology 21 179-187.

Oliveira CA, Zhou Q, Carnes K, Nie R, Kuehl DE, Jackson GL, Franca LR, Nakai M \& Hess RA 2002 ER function in the adult male rat: short- and long-term effects of the antiestrogen ICI 182,780 on the testis and efferent ductules, without changes in testosterone. Endocrinology 143 2399-2409.

Patrizio P \& Salameh WA 1998 Expression of the cystic fibrosis transmembrane conductance regulator (CFTR) mRNA in normal and pathological adult human epididymis. Journal of Reproduction and Fertility Supplement 53 261-270.

Peters CA, Maizels ET, Robertson MC, Shiu RP, Soloff MS \& HunzickerDunn M 2000 Induction of relaxin messenger RNA expression in response to prolactin receptor activation requires protein kinase $\mathrm{C}$ delta signaling. Molecular Endocrinology 14 576-590.

Pietrement C, Da Silva N, Silberstein C, James M, Marsolais M, Van Hoek A, Brown D, Pastor-Soler N, Ameen N, Laprade R et al. 2008 Role of NHERF1, cystic fibrosis transmembrane conductance regulator, and CAMP in the regulation of aquaporin 9. Journal of Biological Chemistry 283 2986-2996.

Pillai SB, Jones JM \& Koos RD 2002 Treatment of rats with $17 \beta$-estradiol or relaxin rapidly inhibits uterine estrogen receptor beta1 and beta2 messenger ribonucleic acid levels. Biology of Reproduction 67 1919-1926.

Quattrone S, Chiappini L, Scapagnini G, Bigazzi B \& Bani D 2004 Relaxin potentiates the expression of inducible nitric oxide synthase by endothelial cells from human umbilical vein in in vitro culture. Molecular Human Reproduction 10 325-330.

Quinton PM 1990 Cystic fibrosis: a disease in electrolyte transport. FASEB Journal 4 2709-2717.

Revankar CM, Cimino DF, Sklar LA, Arterburn JB \& Prossnitz ER 2005 A transmembrane intracellular estrogen receptor mediates rapid cell signaling. Science 307 1625-1630.

Riccioli A, Dal Secco V, De Cesaris P, Starace D, Gandini L, Lenzi A, Dondero F, Padula F, Filippini A \& Ziparo E 2005 Presence of membrane and soluble forms of Fas ligand and of matrilysin (MMP-7) activity in normal and abnormal human semen. Human Reproduction 20 2814-2820.

Rowe SM, Miller S \& Sorscher EJ 2005 Cystic fibrosis. New England Journal of Medicine 352 1992-2001.

Rozen S \& Skaletsky H 2000 Primer3 on the WWW for general users and for biologist programmers. Methods in Molecular Biology 132 365-386.

Rudolph-Owen LA, Cannon P \& Matrisian LM 1998 Overexpression of the matrix metalloproteinase matrilysin results in premature mammary gland differentiation and male infertility. Molecular Biology of the Cell $\mathbf{9}$ 421-435.

Ruz R, Andonian S \& Hermo L 2004 Immunolocalization and regulation of cystic fibrosis transmembrane conductance regulator in the adult rat epididymis. Journal of Andrology 25 265-273.

Samuel CS, Tian H, Zhao L \& Amento EP 2003 a Relaxin is a key mediator of prostate growth and male reproductive tract development. Laboratory Investigation 83 1055-1067.

Samuel CS, Zhao C, Bathgate RA, Bond CP, Parry LJ, Summers RJ, Tang ML, Amento EP \& Tregear GW 2003b Relaxin deficiency in mice is associated with an age-related progression of pulmonary fibrosis. FASEB Journal 17 121-123.

Samuel CS, Zhao C, Bathgate RA, Du XJ, Summers RJ, Amento EP, Walker LL, McBurnie M, Zhao L \& Tregear GW 2005 The relaxin geneknockout mouse: a model of progressive fibrosis. Annals of the New York Academy of Sciences 1041 173-181.

Sasaki Y, Kohsaka T, Kawarasaki T, Sasada H, Ogine T, Bamba K \& Takahara H 2001 Immunoreactive relaxin in seminal plasma of fertile boars and its correlation with sperm motility characteristics determined by computer-assisted digital image analysis. International Journal of Andrology 24 24-30.

Sherwood OD 1994 Relaxin. In The Physiology of Reproduction, edn 2, pp 861-1009. Eds E Knobil \& JD Neill. New York: Raven Press.

Sherwood OD 2004 Relaxin's physiological roles and other diverse actions. Endocrine Reviews 25 205-234.

Sherwood OD, Golos TG \& Key RH 1986 Influence of the conceptuses and the maternal pituitary on the distribution of multiple components of serum relaxin immunoactivity during pregnancy in the rat. Endocrinology 119 2143-2147.

Siebel AL, Gehring HM, Reytomas IG \& Parry LJ 2003 Inhibition of oxytocin receptor and estrogen receptor-alpha expression, but not relaxin receptors (LGR7), in the myometrium of late pregnant relaxin gene knockout mice. Endocrinology 144 4272-4275.

Sokol RZ, Wang XS, Lechago J, Johnston PD \& Swerdloff RS 1989 Immunohistochemical localization of relaxin in human prostate. Journal of Histochemistry and Cytochemistry 37 1253-1255.

Soloff MS, Shaw AR, Gentry LE, Marquardt H \& Vasilenko P 1992 Demonstration of relaxin precursors in pregnant rat ovaries with antisera against bacterially expressed rat prorelaxin. Endocrinology 130 1844-1851.

Steinetz BG, Schwabe C, Callard IP \& Goldsmith LT 1998 Dogfish shark (Squalus acanthias) testes contain a relaxin. Journal of Andrology 19 110-115.

Thomas P, Pang Y, Filardo EJ \& Dong J 2005 Identity of an estrogen membrane receptor coupled to a $G$ protein in human breast cancer cells. Endocrinology 146 624-632.

Thompson VC, Morris TG, Cochrane DR, Cavanagh J, Wafa LA, Hamilton T, Wang S, Fazli L, Gleave ME \& Nelson CC 2006 Relaxin becomes upregulated during prostate cancer progression to androgen independence and is negatively regulated by androgens. Prostate $\mathbf{6 6}$ 1698-1709.

Trezise AE, Linder CC, Grieger D, Thompson EW, Meunier $H$, Griswold MD \& Buchwald M 1993 CFTR expression is regulated during both the cycle of the seminiferous epithelium and the oestrous cycle of rodents. Nature Genetics 3 157-164.

van der Ven K, Messer L, van der Ven H, Jeyendran RS \& Ober C 1996 Cystic fibrosis mutation screening in healthy men with reduced sperm quality. Human Reproduction 11 513-517.

Xu WM, Shi QX, Chen WY, Zhou CX, Ni Y, Rowlands DK, Yi Liu G, Zhu H, Ma ZG, Wang XF et al. 2007 Cystic fibrosis transmembrane conductance regulator is vital to sperm fertilizing capacity and male fertility. PNAS 104 9816-9821. 
Yan W, Ryan PL, Bartol FF \& Bagnell CA 2006 Uterotrophic effects of relaxin related to age and estrogen receptor activation in neonatal pigs. Reproduction 131 943-950.

Yan W, Chen J, Wiley AA, Crean-Harris BD, Bartol FF \& Bagnell CA 2008 Relaxin (RLX) and estrogen affect estrogen receptor alpha, vascular endothelial growth factor, and RLX receptor expression in the neonatal porcine uterus and cervix. Reproduction 135 705-712.

Yasuhara F, Gomes GR, Siu ER, Suenaga Cl, Maróstica E, Porto CS \& Lazari MF 2008 Effects of the antiestrogen fulvestrant (ICl 182,780) on gene expression of the rat efferent ductules. Biology of Reproduction $\mathbf{7 9}$ 432-441.

Yki-Järvinen H, Wahlström T \& Seppälä M 1983 Immunohistochemical demonstration of relaxin in the genital tract of men. Journal of Reproduction and Fertility 69 693-695.

Zarreh-Hoshyari-Khah R, Bartsch O, Einspanier A, Pohnke Y \& Ivell R 2001 Bioactivity of recombinant prorelaxin from the marmoset monkey. Regulatory Peptides 97 139-146.
Zhang Q \& Bagnell CA 1993 Relaxin stimulation of porcine granulosa cell deoxyribonucleic acid synthesis in vitro: interactions with insulin and insulin-like growth factor I. Endocrinology 132 1643-1650.

Zini A, O'Bryan MK, Magid MS \& Schlegel PN 1996 Immunohistochemical localization of endothelial nitric oxide synthase in human testis, epididymis, and vas deferens suggests a possible role for nitric oxide in spermatogenesis, sperm maturation, and programmed cell death. Biology of Reproduction 55 935-941.

Zini A, O'Bryan MK \& Schlegel PN 2001 Nitric oxide synthase activity in human seminal plasma. Urology 58 85-89.

Received 17 April 2009

First decision 9 June 2009

Revised manuscript received 24 September 2009

Accepted 7 October 2009 